AL-IQTISHOD: Jurnal Pemikiran dan Penelitian Ekonomi Islam

E-ISSN: 2745-85I2 P-ISSN: 2407-6600

Volume 9 Issue 2 Juli 202I | Page: 68-93

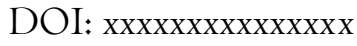

\title{
Produktivitas Baitul Maal Wat Tamwil Khoiru Ummah dalam Meningkatkan Kemaslahatan Masyarakat Pesantren Gresik
}

\author{
Sutono \\ STAI Al-Azhar Menganti Gresik \\ sutonostaialazhar@gmail.com
}

\begin{abstract}
This research with the theme Baitul Maal wat Tamwil Productivity (BMT) Khoiru Ummah in Improving the Welfare of the Community of Darul Ihsan Islamic Boarding School in Gresik, with the formulation of the problem how the form of Productivity of Khoiru Ummah BMT as a manifestation of the running of the community's economy in the pesantren with the form of the welfare of the pesantren community. With that problem, the writer describes it by using qualitative research methods. As for the data collection technique, the right one for the author is to use a technique through observation or observing the process of the running of the economy of the pesantren community through Baitul maal wat Tamwil mediation which is carried out every day. business activities through a transaction agreement with BMT hoiru Ummah. By going through documentation or taking important data to support this research data. The results of this research are Baitul Maal wat Tamwil (BMT) Khoiru Ummah as an institution that collects funds, distributes funds, and distributes services to fulfill the welfare of the life of the pesantren community in Gresik.
\end{abstract}

Keywords : BMT Productivity, Community Benefits.

Abstrak: Penelitian ini dengan tema Produktivitas Baitul Maal wat Tamwil (BMT)Khoiru Ummah Dalam Meningkatkan Kesejahteraan Masyarakat Pondok Pesantren Darul Ihsan di Gresik, dengan rumusan permasalahan bagaimana bentuk Produktivitas BMT Khoiru Ummah sebagai wujud berjalannya perekonomian masyarakat di pesantren dengan bentuk kesejahteraan masyarakat pesantren. Dengan permasalahan itu maka penulis menguraikan nya dengan menggunakan metode penelitian kualitatif. Adapun teknik pengumpulan datanya maka yang tepat bagi penulis adalah dengan menggunakan teknik melalui observasi atau mengamati proses berjalannya roda perekonomian masyarakat pesantren melalui mediasi Baitul maal wat Tamwil yang dilakukan setiap hari.Melalui wawancara atau bertanya, tegur sapa dengan sebagian besar masyarakat pesantren yang terlibat langsung dengan kegiatan bisnis melalui akad transaksi dengan BMT hoiru Ummah. Dengan melalui dokumentasi atau mengambil data penting untuk mendukung data penelitian ini. Adapun hasil dari riset ini adalah Baitul Maal wat Tamwil (BMT) Khoiru Ummah sebagai lembaga penghimpun dana, penyaluran dana, dan penyaluran jasa demi memenuhi kemaslahatankehidupan masyarakat pesantren di Gresik.

Kata Kunci: Produktivitas BMT, Kemaslahatan Masyarakat. 
Produktivitas Baitul Maal Wat Tamwil ...

\section{A. Pendahuluan}

Sistem ekonomi syariah semakin hari perkembangannya semakin dikenal di masyarakat. Tak hanya untuk kalangan Islam semata, tetapi juga bagi mereka yang non muslim. Ini ditandai dengan makin banyaknya nasabah-nasabah pada bank yang menerapkan konsep syariah. Melihat perkembangan itu, tidak tertutup kemungkinan pada masa mendatang seluruh aspek perekonomian akan berbasiskan syariah. Ini menunjukkan nilai-nilai Islam dapat diterima di berbagai kalangan karena sifatnya yang universal, tidak eksklusif dan tentu saja memiliki output yang kompetitif dengan perbankan konvensional.

Satu persamaan antara bank syariah dan bank konvensional adalah kedua-duanya berusaha mencari keuntungan yang sebesar-besarnya. Tentu saja dengan tujuan tersebut, bank syariah dituntut untuk berkembang dan menjadi lembaga finansial yang bonafid dan profesional. Artinya, bank syariah dalam menajemen investasi dan finansial juga dituntut untuk menggunakan asas profit oriented sebagaimana bank konvensional. Maka bank syariah bukan sekedar menggunakan jalur emosional keagamaan untuk menjaring nasabahnya. Itulah salah satu persamaan yang bisa dijadikan referensi dan motivasi dalam mengembangkan kebijakan-kebijakan perbankan syariah.

Di sisi lain, Bank Syariah juga mempunyai tugas dan kewajiban yang harus diembannya, yaitu menjalankan pertumbuhan ekonomi berdasarkan ketentuan syariah, dimana usaha mencari keuntungan yang sebesar-besarnya itu harus didasarkan pada pedoman yang telah ditetapkan syariah, disinilah letak simpul perbedaannya. Dewasa ini semakin banyak bermunculan bank-bank yang menggunakan sistem syariah. Bahkan tak sedikit bank-bank syariah yang merupakan konversi dari bank-bank konvesional mapan yang mencoba sebuah alternative lain untuk menggaet nasabah sebanyak-banyaknya.

Bermunculnya lembaga keuagan bank dan non bank yang berlabel syariahmerupakan jawaban atas kebutuhan masyarakat muslim terhadap produk-produk ekonomi islam. Meningkatnya kebutuhan masyarakat terhadap produk ekonomi islam juga merupakan tantangan bagi lembaga keuangan islam. Tantangan untuk terus berinovasi menselaraskan produk-produknya agar sesuai dengan prinsip hidup Islam. Salah satu dari 
lembaga keuangan non bank adalah BMT khoiru Ummah yang menjadi obyek penelitian ini. ${ }^{1}$

Ada sejumlah alasan mengapa lembaga non perbankan seperti Baitul Maal wat Tamwil yang ada sekarang ini mulai dilirik oleh para pelaku bisnis, di antaranya adalah pasar potensial karena mayoritas penduduk Indonesia beragama Islam dan dengan semakin tumbuhnya kesadaran mereka untuk berperilaku secara Islami termasuk didalamnya yaitu aspek muamalah atau bisnis. Ini diperkuat dengan keluarnya fatwa MUI tentang haramnya bunga bank. Sehingga nasabah muslim dengan kesadarannya mencari alternatif yang sesuai dengan keyakinan mereka.

Alasan kedua, yaitu sistem bagi hasil terbukti lebih menguntungkan dan tangguh dalam menghadapi goncangan krisis moneter. Belajar dari pengalaman ketika krisis moneter melanda Indonesia pada 1997, sejumlah bank terutama bank konvensional goncang dan akhirnya dilikuidasi karena mengalami negative spread, yang akhirnya tidak mampu menunaikan kewajibannya kepada masyarakat. Kebijakan bunga tinggi yang diterapkan pemerintah selama krisis berlangsung telah membuat bank-bank Konvensional (dengan sistem bunga) mengalami bunga negatif (negative spread) Akibatnya dalam masa satu tahun saja, 64 bank terlikuidasi dan 45 lainnya bermasalah yang masuk dalam Bank Beku Operasi (BBO) yang berada di bawah pengawasan Badan Penyehatan Perbankan Nasional(BPPN).

Hal ini terjadi karena bank harus membayar bunga simpanan nasabah yang jauh lebih tinggi dari pada bunga kredit yang diterimanya dari debitur. Kondisi tersebut tidak berpengaruh sama sekali terhadap perbankan syariah dan lembaga non perbankan seperti BMT(yang memakai sistem bagi hasil). Hal ini terjadi disebabkan karena tidak dibebani kewajiban untuk membayar bunga simpanan kepada para nasabahnya Bank syariah hanya membayar bagi hasil kepada nasabahnya sesuai dengan margin keuntungan yang diperoleh

${ }^{\mathrm{I}}$ Muhammad Fakhruddin Mudzakkir and Andi Nu Graha, "Tinjauan Syariah Tentang Penerapan Akad Ijarah Al Muntahiyah Bi Al-Tamlik Di Perusahaan Leasing Syariah,” An-Nisbah: Jumal Ekonomi Syariah I, no. 2 (April I5, 2015): 69-84, https://doi.org/I0.2I274/an.2015.1.2.69-84.

\section{Volume. 9/No. 2/Juli 202I Al-Iqtishod|69}


Produktivitas Baitul Maal Wat Tamwil ...

bank, dengan sistem ini bank syariah tidak akan mengalami negative spread sebagaimana dialami oleh perbankan konvensional yang memakai sistem bunga.

Ini semua membuktikan bahwa konsep ekonomi Islam diminati oleh semua kalangan lintas keyakinan. Jelas ini sebuah peluang bisnis dan investasi yang menggoda. Masih adanya bank-bank syariah yang berbau kapitalis tentu harus menjadi perhatian semua pihak, artinya bank hanya memberikan bantuan kepada pemilik usaha besar saja, sedangkan pemilik usaha menengah ke bawah tidak mendapat bantuan sama sekali atau kecil kemungkinan mendapat hak yang sama dengan pemilik usaha bermodal besar.Padahal keadilan juga merupakan bagian dari syariatIslam. Kemudian mengoperasionalisasikan secara konsisten filosofi dasar Baitul Maal wat Tamwil Khoiru Ummah yang berbeda dengan filosofi dasar bank konvensional. Bahwa mu'amalah atau bisnis yang dilakukan adalah dalam rangka ibadah untuk mendapatkan ridha Allah Swt. Maka setiap bankir ataupun mereka yang terlibat dalarn menggiatkan Baitul Maal wat Tamwil Khoiru Ummah sudah seharusnya menggunakan kacamata Islam dalam memandang kehidupan, tak hanya dalam satu aspek saja. Sehingga pelaksanaan syariat Islam tidak terkesan parsial atau pragmatis.

Sejak langkah pertama pendiriannya, Baitul Maal wat Tamwil Khoiru Ummahtelah menunjukkan trend perkembangan yang positif sehingga dapat memainkah peranan pentingnya dalam memobilisasi, mengalokasi, dan memanfaatkan sumber daya dengan lebih baik. Salah satu faktor pendukung yang menunjang trend positif ini adalah pembagian hasil usaha dalam pembiayaan yang menggunakan konsep profit sharing dan revenue sharing dengan akad mudharabah, meski pada awalnya konsep ini tidak begitu luas dimengerti oleh masyarakat. Profit sharing dan revenue sharing merupakan pembagian hasil usaha dengan ketentuan nisbah pihak penyalur dana dan penerima dana usaha. Sehingga besarnya pembagian dipengaruhi oleh hasil usaha yang dijalani.

Konsep profit sharing atau yang juga disebut dengan profit and loss sharing menawarkan pembagian hasil usaha dengan perhitungan pendapatan/keuntungan bersih (net profit), yaitu laba kotor dikurangi beban biaya yang dikeluarkan selama operasional 
usaha. Sedangkan konsep revenue sharing adalah konsep yang menawarkan pembagian hasil usaha berdasarkan perhitungan laba kotor (gross profit).

Kosep inilah yang membedakannya dengan bank-bank konvensional yang menawarkan tingkat suku bunga yang tinggi agar dapat menarik minat masyarakat menabungkan uangnya di bank. Besarnya bunga dalam pembagian hasil usaha ditetapkan pada awal perjanjian kerjasama dengan keuntungan yang pasti bagi investor. Bahkan meski kreditur mengalami kerugian dalam usahanya, investor tetap mendapatkan bunga yang disepakati sebelumnya.

Berdasarkan latar belakang masalah tersebut, dapat diketahui bahwa konsep bagi hasil yang diterapkan dalam Baitul Maal wat Tamwil Khoiru Ummah dan bank konvensional memiliki perbedaan dalam keuntungan yang diperoleh dalam pembiayaan/investasi usaha produktif yang dikembangkan kreditur. Profit sharing dan revenue sharing merupakan pengganti bunga dalam perbankan konvensional.

Sama seperti halnya dengan bank konvensional, Baitul Maal wat Tamwil Khoiru Ummahjuga menawarkan nasabah dengan produk perbankan. Hanya saja bedanya dengan bank konvensional adalah dalam hal penentuan harga, baik terhadap harga jual maupun harga belinya. Produk-produk yang ditawarkan sudah tentu sangat Islami, termasuk dalam memberikan pelayanan kepada nasabahnya.

Oleh karena itu, dalam pembahasan kali ini penulis akan mencoba menguraikan beberapa produk-produk yang ada di Baitul Maal wat Tamwil Khoiru Ummah serta menguraikan bentuk kemaslahatan yang diperoleh masyarakat pesantren di Gresik.

\section{B. Kajian Pustaka}

Penelitian yang dilakukan oleh sutono, beliau mengatakan bahwa berkembangnya Perbankan Syari'ah seiring dengan berkembangnya produk-produk di dalamnya. Salah satu produk perbankan syariah yang sangat diminati oleh masyarakat adalah produk pembiayaan perumahan yang dikenal dengan istilah Kongsi Pemilikan Rumah Syari’ah 
Produktivitas Baitul Maal Wat Tamwil ...

(KPRS). Dalam implementasinya menggunakan akad Murabahah dan Musyarakah mutanaqishah. ${ }^{2}$

Penelitian yang yang dilakukan olehRahmat Ilyas beliau mengatakan bahwadalam pelaksanaan pembiayaan, bank syari'ah harus memenuhi dua aspek yang sangat penting, yaitu: (I) aspek syar'i, di mana dalam setiap realisasi pembiayaan kepada para nasabah, bank syari' ah harus tetap perpedoman pada syari'at Islam; dan (2) aspek ekonomi, yakni tetap mempertimbangkan perolehan keuntungan, baik bagi bank syari'ah maupun bagi nasabah bank syari' ah. ${ }^{3}$

Penelitian yang dilakukan oleh Ahmad Syifaul anam beliau meyimpulkan bahwa ada sebagian besar BMT di kota Semarang, tidak menerapkan hukum jaminan seperti yang diharapkan pada peraturan yang dimaksud (law inbook). Di sana ditemukan penyimpangan penyimpangan: beragamnya barang jaminan yang dipakai, pengikatan barang jaminan yang hanya di bawah tangan, eksekusinya barang jaminan sering juga hanya dilakukan hanya bawah tangan yang rawan terhadap penyimpangan. Pelaksanaan hukum jaminan tersebut tidak mempunyai kekuatan hukum eksekutorial. Penyelesaian sengketa hanya bisa dilakukan secara musyawarah tidak sampai pada upaya litigasi ke pengadilan. Jika upaya non litigasi tidak berhasil dan upaya litigasi tidak mempunyai dasar kekuatan hukum maka yang terjadi adalah penyitaan dengan pemaksaaan untuk selanjutnya dilakukan eksekusi barang jaminan. ${ }^{4}$

\section{Metode Penelitian}

Metode penelitian yang penulis gunakan adalah pendekatan kualitatif dengan teknik pengumpulan data melalui cara observasi, wawancara, dan dokumentasi terkait dengan

\footnotetext{
2 Sutono, "IMPLIKASI AKAD MUSYARAKAH MUTANAQISAH PERBANKAN SYARI'AH (Studi Peluang Dan Resiko Di Bank Mu'amalat Surabaya)," AL-IQTISHOD: Jurnal Pemikiran Dan Penelitian Ekonomi Islam 8, no. 2 (July 2020): I-I9.

${ }^{3 R a h m a t}$ Ilyas, "Etika Konsumsi dan Kesejahteraan dalam Perspektif Ekonomi Islam.," at- Tawassuth I, no. I (2016): I 52-72.

${ }^{4}$ Ahmad Syifaul Anam, "IMPLEMENTASI HUKUM JAMINAN LEMBAGA KEUANGAN MIKRO SYARI’AH (STUDI KASUS BMT DI KOTA SEMARANG),” Universitas Diponegoro, 2009, I-I2I.
} 
sistem aqad trasaksi dan manajemen Baitul Maal wat Tamwil KSPPS Khoiru Ummah Jatim. Adapun sumber informasi atau key informan 5 dan informan yang lain.6

\section{Hasil dan Pembahasan}

\section{BMT KSPPS Khoiru Ummah Sebagai Penghimpunan Dana}

a. Mudharabah

Mudharabah adalah akad kerjasama usaha antara pemilik modal dan pengelola usaha untuk melakukan kegiatan usaha, laba dibagi atas dasar nisbah bagi hasil menurut kesepakatan kedua belah pihak, sedangkan bila terjadi kerugian akan ditanggung oleh si pemilik modal kecuali kerugian yang disebabkan oleh kesalahan pengelola usaha.

Akad mudharabah merupakan suatu transaksi pendanaan atau investasi yang berdasarkan kepercayaan, yaitu kepercayaan dari pemilik modal kepada pengelola usaha. Kepercayaan ini penting dalam akad mudharabah karena pemilik modal tidak boleh ikut campur dalam manajemen perusahaan atau proyek yang dibiayai dengan pemilik modal tersebut, kecuali sebatas memberikan saran dan melakukan pengawasan pada pengelola usaha. ${ }^{7}$

Dalam mudharabah, pemilik modal tidak boleh mengisyaratkan sejumlah tertentu untuk bagiannya karena dapat dipersamakan dengan riba yaitu meminta kelebihan atau imbalan tanpa ada faktor penyeimbang yang diperbolehkan syariah.

\footnotetext{
${ }^{5}$ Suwandi, (Direktur BMT KSPPS Khoiru Ummah), Wawancara, Gresik, 20 Desember, 2020.

${ }^{6}$ Nur Hudah (Ketua BMT KSPPS Khoiru Ummah), Wawancara, Gresik, 2I Desember, 2020.

7 kambali, muhammad. 202I. "PRODUK OPERASIONALISASI BANK SYARI'AH : STUDI PENERAPAN PRINSIP SYARI'AH PADA BANK SYARI'AH MANDIRI (BSM) DAN BANK ISLAM MALASYA BERHARD (BIMB)”. AL IQTISHOD: Jurnal Pemikiran Dan Penelitian Ekonomi Islam 9 (I), 20-35. https://jurnal.stai-alazharmenganti.ac.id/index.php/AlIqtishod/article/view/225.
}

Volume. 9/No. 2/Juli 202I A1-Iqtishod|73 
Produktivitas Baitul Maal Wat Tamwil ...

Keuntungan yang dibagikan pun tidak boleh menggunakan nilai proyeksi, akan tetapi harus menggunakan nilai realisasi keuntungan yang mengacu pada laporan hasil usaha yang secara periodik disusun oleh pengelola usaha dan diserahkan kepada pemilik modal. ${ }^{8}$

Menurut ijmal ulama, mudharabah hukumnya jaiz (boleh). Mudharabah telah dipraktikkan secara luas oleh orang-orang sebelum masa islam dan beberapa sahabat Nabi Muhammad saw. Jenis bisnis ini sangat bermanfaat dan sangat selaras dengan prinsip ajaran syariah, oleh karena itu masih tetap ada di dalam sistem Islam. Mudharabah di bagi menjadi 3 jenis, diantaranya:

\section{Mudharabah Muthlaqah}

Mudharabah muthlaqah adalah jenis mudharabah dimana pemilik dana memberikan kebebasan kepada pengelola usaha dalam mengelola investasinya. Mudharabah ini disebut juga investasi tidak terikat. Jenis mudharabah ini tidak ditentukan masa erlakunya, didaerah mana usaha tersebut akan dilakukan. Namun, kebebasan ini bukan kebebasan yang tak terbatas sama sekali. Modal yang ditanamkan tetap tidak boleh digunakan untuk membiayai proyek atau investasi yang dilarang islam.

\section{Mudharabah Muqayyadah}

Mudharabah muqayyadah adalah jenis mudharabah dimana pemilik dana memberikan batasan kepada pengelola antara lain mengenai dana, lokasi, cara dan objek investasi atau sektor usaha. Apabila pengelola dana bertindak bertentangan dengan syarat-syarat yang diberikan oleh pemilik

${ }^{8}$ Kautsar riza salman, Akuntansi perbankan syariah, (padang:Akademia Permata, 2012), hal.219. 
dana, maka pengelola dana harus bertanggung jawab atas konsekuensikonsekuensi yang ditimbulkannya, termasuk konsekuensi keuangan.

\section{Mudharabah Musytarakah}

Mudharabah musytarakah adalah jenis mudhrabah dimana pengelola dana menyertakan modal dana nya dalam kerja sama investasi. Di awal kerja sama, akad ynag disepakati adalah akad mudharabah dengan modal I00\% dari pemilik dana, setelah berjalannya operasi usaha dengan pertimbangan tertentu dengan kesepakatan dengan pemilik dana, pengelola dana ikut menanamkan modalnya dalam usaha tersebut. Jenis mudharabah seperti ini adalah perpaduan antara akad mudharabah dan akad musyarakah (syirkah).

Rukun dari akad mudharabah ada empat, yaitu:

I. Pelaku, terdiri atas: pemilik dana dan pengelola dana

2. Objek mudharabah, berupa: modal dan kerja

3. Ijab kabul / serah terima

4. Nisbah keuntungan

b. Wadiah

Secara etimologis, kata wadi'ah berasal dari kata wada'a asy-syai' jika ia meninggalkannya pada orang yang menerima titipan. Adapun wadi'ah secara terminologis, yaitu pemberian kuasa oleh penitip kepada orang yang menjaga hartanya tanpa konpensasi (ganti). ${ }^{9}$

Jadi, dapat disimpulkan bahwa wadiah adalah Wadiah yaitu akad titipan dimana barang yang dititipkan dapat diambil sewaktu-waktu.Pihak

${ }^{9}$ Mardani, Fiqh Ekonomi Syariah, (jakarta: kencana prenadamedia group,2013), 282.

Volume. 9/No. 2/Juli 202I A1-Iqtishod|75 
Produktivitas Baitul Maal Wat Tamwil ...

yang menerima titipan dapat meminta jasa untuk keamanan dan pemeliharaan. ${ }^{10}$

Rukun wadi'ah

I) Muwaddi/ penitip

2) Mustauda/ penerima titipan

3) Wadiah bih/ harta titipan

4) Akad

Pembagian Wadi'ah Secara umum terdapat dua jenis wadiah, yaitu:

I. Wadiah yad al-amanah. Wadiah jenis ini memiliki karakteristik sebagai berikut:

a. Harta atau barang yang dititipkan tidak boleh dimanfaatkan dan digunakan oleh penerima titipan

b. Penerima titipan hanya brfungsi sebagai penerima amanah yang bertugas dan berkewajiban untuk menjaga barang yang dititipkan tanpa boleh memanfaatkannya

c. Sebagai kompensasi, penerima titipan diperkenankan untuk membebankan biaya kepada yang menitipkan

d. Mengingatkan barang atau harta yang dititipkan tidak boleh dimanfaatkan oleh penerima titipan, aplikasi perbankan yang memungkinkan untuk jenis in adalah jasa penitipan

2. Wadiah yad adh-dhamanah. Wadiah jenis ini memiliki karakteristik Harta dan barang yang dititipkan boleh dan dapat dimanfaatkan oleh

${ }^{10}$ M. Nur Rianto, Dasar-dasar pemasaran bank syariah, (bandung: alfabeta, 20I2), 36. 
yang menerima titipan Karena dimanfaatkan, barang dan harta yang yang dititipkan tersebut tentu dapat menghasilkan manfaat. Sekalipun demikian, tidak ada keharusan bagi penerima titipan untuk memberikan hasil manfaat kepada si penitip.

\section{BMT KSPPS sebagai Penyaluran Dana}

a. Jual Beli

I. Murabahah

Jual beli murabahah adalah pembelian oleh satu pihak untuk kemudian dijual kepada pihak lain yang telah mengajukan permohonanpembelian terhadap suatu barang dengan keuntungan atau tambahan harga yang transparan.

Pembayaran murabahah dapat dilakukan secara tunai atau cicilan. Harga yang disepakati dalam murabahah adalah harga jual sedangkan harga beli harus diberitahukan. ${ }^{\mathrm{II}}$ Jenis-jenis murabahah antara lain :

a) Murabahah berdasarkan Pesanan

Dalam murabahah jenis ini, penjual melakukan pembelian barang setelah ada pemesanan dari pembeli. Murabahah dengan pesanan dapat bersifat mengikat atau tidak mengikat pembeli untuk membeli barang yang dipesannya. Murabahah yang bersifat mengikat berarti pembeli harus membeli barang yang dipesannya dan tidak bisa membatalkan pesanannya. Adapun murabahah yang bersifat tidak mengikat walaupun telah memesan barang tetapi

"Mardani, Fiqh Ekonomi Syariah, (jakarta: kencana prenadamedia group,20I3), hal. I36

Volume. 9/No. 2/Juli 202I A1-Iqtishod|77 
Produktivitas Baitul Maal Wat Tamwil ...

pembeli tersebut tidak terikat maka pembeli dapat menerima atau membatalkan barang tersebut.

b) Murabahah Tanpa Pesanan

Murabahah jenis ini termasuk jenis murabahah yang bersifat tidak mengikat. Murabahah ini dilakukan tidak melihat ada yang pesan atau tidak sehingga penyediaan barang dilakukan sendiri oleh penjual.

Adapun Rukun dan Ketentuan Murabahah diatur dalam ketentuan sebagi berikut :

I. Pelaku

Pelaku harus cakap hukum dan balig (berakal dan dapat membedakan), sehingga jual beli dengan orang gila menjadi tidak sah sedangkan jual beli dengan anak kecil dianggap sah apabila seizin walinya.

2. Objek jual beli harus memenuhi:

- Barang yang diperjualbelikan adalah barang halal

- Barang yang di perjual belikan harus bermanfaat

- Barang tersebut dimiliki oleh penjual

- $\quad$ Barang yang diperjual belikan harus jelas spesifikasinya

- Barang harus diketahui kuantitas dan kualitasnya

- Harga barang harus jelas

- Barang yang di akadkan ada ditangan penjual

3. Ijab kabul

78| Al-Iqtishod Volume. 9/No. 2/Juli 202I 
Penyataan rida/rela diantara pihak-pihak pelaku akad yang dilakukan secara verbal, tertulis melalui korespondensi atau menggunakan cara-cara komunikasi modern. Apabila jual beli telah dilakukan sesuai dengan ketentuan syariah maka kepemilikannnya, pembayarannya, dan pemanfaatannnya atas barang yang diperjualbelikan menjadi halal. Demikian sebaliknya.

2. Salam

Salam berasal dari kata As salaf yang artinya pendahuluan karena pemesan barang menyerahkan uang dimuka. Akad salam dapat didefinisikan sebagai transaksi atau akad jual beli dimana barang yang diperjual belikan belum ada ketika transaksi dilakukan, dan pembeli melakukan pembayaran dimuka sedangkan penyerahan barang baru dilakukan dikemudian hari. ${ }^{12}$

Menurut Kompilsi Hukum Ekonomi Syariah, salam adalah jasa pembiayaan yang berkaitan dengan jual beli yang pembiayaannnya dilakukan dengan pemesanan barang. ${ }^{13}$

Manfaat transaksi salam bagi pihak pembeli adalah adanya jaminan memperoleh barang dalam jumlah dan kualitas tertentu pada saat ia membutuhkan dengan harga yang disepakatinya di awal. Sementara manfaat bagi si penjual adalah diperolehnya dana untuk melakukan aktivitas produksi dan memenuhi sebagian kebutuhan hidupnya.

Dalam akad salam, harga barang pesanan yang sudah disepakati tidak dapat berubah selama jangka waktu akad. Apabila barang yang

${ }^{12}$ Kautsar Riza Salman, Akuntansi Perbankan Syariah (padang:Akademia Permata, 2012), 173

${ }^{13}$ Mardani, Fiqh Ekonomi Syariah, (Jakarta: kencana prenadamedia group, 2013), II3.

Volume. 9/No. 2/Juli 202I A1-Iqtishod|79 
Produktivitas Baitul Maal Wat Tamwil ...

dikirim tidak sesuai dengan ketentuan yang telah disepakati sebelumnya, maka pembeli boleh melakukan khiar yaitu memilih apakah transaksi dilanjutkan atau dibatalkan. Untuk menghindari risiko yang merugikan, pembeli boleh meminta jaminan dari penjual.

Salam paralel artinya melaksanakan dua transaksi salam yaitu antara pemesan pembeli dan penjual serta antara penjual dengan pemasok atau pihak ketiga lainnya.

Adapun Rukun dan Ketentuan Salam diatur sebagai berikut:

I) Pelaku adalah cakap hukum dan baligh

2) Objek akad:

- Ketentuan yang terkait modal salam

- Harus diketahui jenis dan jumlahnya

- Berbentuk uang tunai

- Diserahkan ketika akad berlangsung

- Ketentuan barang salam:

- Mempunyai spesifikasi yang jelas

- Harus dapat ditakar

- Waktu dan tempat penyerahan barang harus ditetapkan berdasarkan kesepakatan

- Barang tidak harus ada ditangan penjual tapi harus ada pada saat waktu yang ditentukan.

- Apabila barang tidak ada pada waktu yang telah ditentukan maka akad nya menjadi rusak

3) Ijab kabul

80| Al-Iqtishod Volume. 9/No. 2/Juli 202I 
Adalah penyertaan dan ekspresi saling rida/rela diantara pihak-pihak pelaku akad yang dilakukan secara verbal, tertulis, melalui korespondensi atau menggunakan cara-cara komunikasi modern.

3. Istishna

Menurut Kompilasi Hukum Ekonomi Syariah istishna adalah jual beli barang atau jasa dalam bentuk pemesanan dengan kriteria dan persyaratan tertentu yang disepakati antara pihak pemesan dan pihak penjual. $^{14}$

Istishna menurut fukaha adalah pengembangan dari sala, dan diizinkan secara syariah berdasarkan dalil dari alquran dan hadis serta kesepakatan kaum muslimin.

Istishna adalah akad jual beli dalam bentuk pemesanan pembuatan barang tertentu dengan kriteria dan persyaratan tertentu yang disepakati antar pemesan (pembeli) dan penjual (pembuat). Istishna dapat dilakukan secara langsung antar dua belah pihak antar pemesan dengan penjual. Apabila dilakukan melalui perantara maka akad disebut dengan istishna paralel.

Walaupun istishna adalah akad jual beli, tetapi memiliki perbedaan dengan salam maupun dengan murabahah. Istishna lebih dititikberatkan pada kontrak pengadaan barang yang ditangguhkan dan dapat dibayarkan secara tangguh pula. ${ }^{15}$

Dalam istishna paralel penjual dapat membuat akad istishna kedua dengan subkontaktor untuk membantunya memenuhi kewajiban akad

${ }^{14}$ Mardani, Fiqh Ekonomi Syariah, (Jakarta: kencana prenadamedia group,2013), I24.

${ }^{15}$ Kautsar Riza Salman, Akuntansi perbankan syariah, (Padang: Akademia Permata, 2012), 199.

Volume. 9/No. 2/Juli 202I Al-Iqtishod|8I 
Produktivitas Baitul Maal Wat Tamwil ...

istishna pertama (antara penjual dan pemesan) pihak yang bertanggung jawab pada pemesan tetap terletak pada penjual tidak dapat dialihkan pada subkontraktor. Meskipun proses pengerjaan dilakukan oleh subkontraktor, penjual tetap bertanggung jawab atas hasil kerja subkontraktor. Pembeli mempunyai hak untuk memperoleh jaminan dari penjual atas jumlah yang telah dibayarkan, penyerahan barang pesanan sesuai dengan spesifikasi dan tepat waktu.

Adapun Rukun dan Ketentuan Istishna di atur dalam ketentuan sebagai berikut :

a. Transaktor

Terdiri atas pembeli dan penjual. Kedua transaktor diisyaratkan memiliki kompetensi berupa akil balig dan kemampuan memilih yang optimal seperti tidak gila, tidak sedang dipaksa, dll.

b. Objek istishna

Objek istishna harus jelas spesifikasinya, penyerahannya dilakukan kemudian, waktu dan tempat penyerahan barang harus ditetapkan berdasarkan kesepakatan, pembeli tidak boleh menjual barang sebelum menerimanya, tidak boleh menukar barang, kecuali dengan barang sejenis sesuai kesepakatan, dan memerlukan proses pembuatan setelah akad disepakati, serta barang yang diserahkan harus sesuai dengan spesifikasi pemesan, bukan barang masal.

c. Ijab kabul

Ijab kabul istishna merupakan pernyataan dari kedua belah pihak yang berkontrak, dengan cara penawaran dari penjual (bank syariah) dan penerimaan yang dinyatakan oleh pembeli(nasabah).

b. Sewa 
Pembiayaan dengan prinsip sewa ditujukan untuk mendapatkan jasa, dimana keuntungan bank ditentukan didepan dan menjadi bagian harga atas barang atau jasa yang disewakan. Namun dalam beberapa kasus prinsip sewadapat pula disertai dengan opsi kepemilikan. ${ }^{16}$

Yang termasuk dalam kategori sewa adalah :

I) Ijarah

Ijarah adalah akad pemindahan hak guna(manfaat) atas suatu barang atau jasa, dalam waktu tertentu dengan pembayaran upah sewa tanpa diikuti dengan pemindahan kepemilikan atas barang itu sendiri. ${ }^{17}$

Ijarah dimaksudkan untuk mengambil manfaat atas barang atau jasa dengan jalan penggantian. Beberapa contoh kontrak ijarah (pemilikan manfaat) seperti manfaat yang berasal dari aset seperti rumah untuk ditempati, mobil untuk dikendarai atau manfaat yang berasal dari karya seseorang seperti hasil karya seorang insinyur bangunan,tukang tenun, pekerja bangunan, penjahit, dll. Dan manfaat yang be rasal dari skill/keahlian individu seperti pekerja kantor, pembantu rumah tangga, dll.

Akad ijarah mewajibkan pemberi sewa untuk menyediakan aset yang dapat digunakan atau dapat diambil manfaat darinya selam periode akad dan memberikan hak kepada pemberi sewa untuk menerima upah sewa. Apabila terjadi kerusakan yang mengakibatkan penurunan nilai kegunaan dari aset yang disewakan dan bukan disebabkan kelalaian penyewa, pemberi sewa berkewajiban

${ }^{16}$ M. Nur Rianto Al Arif, Dasar-dasar Pemasaran, (Bandung: Alfabeta, 2012), 46.

${ }^{17}$ Kautsar Riza Salman, Akuntansi perbankan syariah, 270.

Volume. 9/No. 2/Juli 202I A1-Iqtishod|83 
Produktivitas Baitul Maal Wat Tamwil ...

menanggung biaya pemeliharaannya selama periode akad atau menggantinya dengan aset yang sejenis.

Pengalihan kontrak atau aset yang disewa kemudian disewakan kembali pada pihak lain boleh dilakukan baik dengan harga sama, lebih tinggi atau lebih rendah asalkan pemberi sewa mengizinkannya.

Pembayaran sewa dapat dibayar dimuka, ditangguhkan ataupun diangsur sesuai kesepakatan antara pemberi sewa dan penyewa. Apabila yang disepakati adalah pembayaran tangguh dan terjadi penundaan pembayaran akibat penyewa lalai, maka dapat dikenakan denda yang akan digunakan sebagai dana kebajikan.

2) Jenis-jenis Ijarah

a. Berdasarkan objek yang disewakan, dibagi menjadi dua yaitu Ijarah yang berhubungan dengan sewa aset atau properti,yaitu memindahkan hak untuk memakai atau properti tertentu kepada orang lain dengan imbalan biaya sewa dan Ijarah yang berhubungan dengan sewa jasa, yaitu mempekerjakan seseorang dengan upah sebagai imbalan jasa yang disewa.

3) Perpindahan kepemilikan dapat dilakukan melalui:

a) Hibah

Penjualan, dimana harga harus disepakati oleh kedua belah pihak sebelum akad penjualan

b) Jual dan sewa kembali (sale and lease back) atau transaksi jual dan ijarah. Jenis ijarah seperti ini terjadi dimana seorang menjual asetnya kepada pihak lain dan menyewakembali aset tersebut.transaksi jual dan sewa kembali harus merupakan transaksi terpisah dan tidak saling bergantung sehingga harga jual

84| Al-Iqtishod Volume. 9/No. 2/Juli 202I 
harus dilakukan pada nilai wajar dan penjual akan mengakui keuntungan atau keutungan pada periode terjadinya penjualan dalam laporan laba rugi.

4) Rukun Ijaroh

- Pelaku yang terdiri atas pemberi sewa dan penyewa

- Objek akad berupa manfaat aset dan pembayaran sewa atau manfaat jasa dan pembayaran upah

- $\quad$ Ijab $\mathrm{kabul} / \mathrm{serah}$ terima

Ijarah Muntahiyah Bittamlik, Ijarah muntahiyah bittamlik adalah akad sewa-menyewa antar pemilik objek sewa dan penyewa untuk mendapatkan imbalan atas abjek sewa yang disewakan dengan opsi perpindahan hak milik objek sewa pada saat tertentu sesuai dengan akad sewa.

Perpindahan hak milik objek sewa kepada penyewa dalam ijarah muntahiyah bittamlik dapat dilakukan dengan:

i. Hibah

ii. Penjualan sebelum akad berakhir sebesar harga yang sebanding dengan sisa cicilan sewa

iii. Penjualan pada akhir masa sewa denga pembayaran tertentu yang disepakati pada awal akad

iv. Penjualan secara bertahap sebesar harga tertentu yang disepakati dan tercantumdalam akad.

v. Pihak yang menyewakan berjanji akan menjual barang ang disewakan tersebut pada akhir masa sewa. 
Produktivitas Baitul Maal Wat Tamwil ...

vi. Pemilik objek sewa dapat meminta penyewa menyerahkan jaminan atas ijarah untuk menghindari resiko kerugian. jumlah, ukuran, dan jenis objek sewa harus jelas diketahui dan tercantum dalam akad.

\section{Akad Pelengkap}

Pembiayaan dengan akad pelengkap ditujukan untuk memperlancar pembiayaan dengan menggunakan tiga prinsip diatas. Berikut akad pelengkap tersebut:

a) Hawalah

Merupakan pengalihan utang dari orang yang berutang kepada orang lain yang wajib menanggungnya. Atau dengan kata lain pemindahan beban utang dari satu pihak kepada lain pihak. Dalam dunia keuangan atau perbankan dikenal dengan kegiatan anjak piutang atau factoring.

Rukun dan syarat hawalah, Rukun hawalah/pemindahan utang terdiri atas Peminjam, Pemberi pinjaman,Penerima hawalah, Utang, Akad.

Syarat Hawalah Menurut kompilasi hukum ekonomi syariah adalah sebagai berikut ${ }^{18}:$

a. Para pihak yang melakukan akad hawalah/pemindahan utang harus memiliki kecakapan hukum

b. Peminjaman harus memberitahu kepada pemberi pinjaman bahwa ia akan memindahkan utangnya kepada pihak lain

c. Persetujuan pemberi pinjaman mengenai pinjaman mengenai rencana peminjam untuk memindahkan utang adalah syarat diperbolehkannya akad hawalah.I9

${ }^{18}$ Mardani, Fiqh Ekonomi Syariah, (Jakarta: Kencana Prenadamedia Group, 2013), 268. 
b) Rahn (gadai)

Gadai adalah perjanjian (akad) pinjam meminjam dengan menyerahkan barang sebagai tanggungan utang. Sehingga dapat disimpulkan gadai adalah menjadikan suatu benda itu berharga sebagai jaminan sebagai tanggungan utang berdasarkan perjanjian (akad) antara orang yang memiliki hutang dengan pihak yang memberi hutang.

Syarat dan Rukun Gadai

a) Syarat gadai antara lain Sehat fikirannya, Dewasa, baligh, Barang yang digadaikan telah ada di waktu gadai, Barang gadai bisa diserahkan/dipegang oleh penggadai

b) Rukun gadai antara lain Orang yang menggadai/orang yang menyerahkan barang jaminan(rahin), Orang yang menerima barang gadai (murtahin), Barang yang dijadikan jaminan(borg/marhun). Akad(ijab dan qobul), Adanya hutang yang dimiliki oleh penggadai.

c) Qardh

Qardh adalah pemberian harta kepada orang lain yang dapat ditagih atau diminta kembali atau dengan kata lain meminjamkan tanpa mengharapkan imbalan. ${ }^{20}$ Rukun Qardh

a) pelaku (muqridh dan muqtaridh)

b) objek (uang atau barang)

c) shighat (ijab dan qabul).

d) Wakalah

${ }^{19}$ Suwandi Ali Syamsi, Wawancara, Gresik, 3 Mei 202 I.

${ }^{20}$ Ibid., 334.

Volume. 9/No. 2/Juli 202I A1-Iqtishod|87 
Produktivitas Baitul Maal Wat Tamwil ...

Wakalah atau wakilah artinya penyerahan atau pendelegasian atau pemberian mandat dari satu pihak kepada pihak lain. Mandat ini harus dilakukan sesuai dengan yang telah disepakati oleh si pemberi mandat. ${ }^{21}$ Syarat dan Rukun wakalah

- Syarat muwakil (yang mewakilkan) Pemilik sah yang dapat bertindak terhadap sesuatu yang diwakilkan

- Syarat wakil (yang mewakili) Cakap hukum, dapat mengerjakan tugas yang diwakilkan kepadanya.

- Hal-hal yang diwakilkan Diketahui dengan jelas oleh orang yang mewakili, tidak bertentangan dengan syariah islam, dapat diwakailkan menurut syariah islam

e) Kafalah

Al-Kafalah merupakan jaminan yang diberikan penanggung kepada pihak ketiga untuk memenuhi kewajiban pihak kedua atau yang ditanggung. Dapat pula diartikan sebagai pengalihan tanggung jawab dari satu pihak kepada pihak lain. Dalam dunia perbankan dapat dilakukan dalam hal pembiayaan dengan jaminan seseorang 22 .

Rukun dan syarat kafalah

a. Pihak penjamin

Balig dan berakal sehat, berhak penuh untuk melakukan tindakan hukum dalam urusan hartanya dan rela dengan tanggungan kafalah tersebut.

b) Pihak orang yang berhutang

${ }^{21}$ Ibid., 300.

${ }^{22}$ M. Nur Rianto Al Arif, Dasar-dasar Pemasaran, (Bandung:Alfabeta, 2012, 57.

88| Al-Iqtishod Volume. 9/No. 2/Juli 202I 
Sanggu menyerahkan tanggungannya kepada penjamin,dan dikenal oleh penjamin.

c) Pihak orang yang berpiutang

Diketahui identitasnya, dapat hadir pada waktu akad atau memberikan kuasa.

d) Objek penjamin

Merupakan tanggungan pihak/orang yang berhutang, baik berupa uang, benda, maupun pekerjaan.

\section{BMT KSPPS Khoiru Ummah Sebagai Pelayanan Jasa}

Selain menjalankan fungsinya sebagai penghubung antara pihak yang kelebihan dana dan kekurangan dana, BMT dapat pula melakukan berbagai pelayanan jasa kepada nasabah dengan mendapat imbalan berupa sewa atau keuntungan. Jasa tersebut antara lain berupa. ${ }^{23}$

I) Sharf (valuta asing)

Pada prinsipnya jual beli valuta asing sejalan dengan prinsip sharf . jual beli mata uang yang tidak sejenis ini, penyerahannya harus dilakukan pada waktu yang sama. Bank mengambil keuntungan dari jual beli valuta asing ini. Prinsip ini dipraktikan pada BMT yang memiliki ijin untuk melakukan jual beli valuta asing.

Dasar hukum sharf

Dari Abu Hurairah dari nabi SAW, bersabda: "(boleh menjual) emas dengan emas dengan setimbang, sebanding, dan perak dengan perak setimbang sebanding." (H.R. Ahmad, Muslim, \& Nasa'i)

Rukun sharf:

a. Penjual

${ }^{23} \mathrm{M}$. Nur Rianto Al Arif, Dasar-dasar pemasaran, 58.

Volume. 9/No. 2/Juli 202I Al-Iqtishod|89 
Produktivitas Baitul Maal Wat Tamwil ...

b. Pembeli

c. Mata uang yang diperjualbelikan(sharf)

d. Nilaitukar (sïrus sharf)

e. Ijab Kabul

\section{BMT Khoiru Ummah sebagai mediasi tumbuhnya Kemaslahatan Masyarakat}

\section{Pondok Pesantren Darul Ihsan Gresik}

Maslahah menurut Imam Al-Ghazali adalah kemaslahatan yang diperoleh seorang manusia sebagai tujuan diturunkan syar ${ }^{\text {ee }}$ adalah untuk memelihara lima hal pokok, yaitu melindungi agama, melindungi nyawa, melindungi akal, melindungi keturunan dan melindungi harta. Kemudian memasukkan lima hal tersebut dengan skala prioritas, dalam pemeliharaan masalah esensial (primer), sekunder dan tersier.24

Sedangkan menurut M. Umer Chapra, Islam menganjurkan kepada seluruh pemeluknya untuk menjalankan ajarannya demi memenuhi kesejahteraan ekonomi melalui pemenuhan semua kebutuhan pokok manusia, menghapuskan semua hal-hal yang mendatangkan kesulitan dan ketidaknyamanan (kemiskinan, pengangguran, kesempatan kerja yang rendah, dan lain-lain), serta meningkatkan kualitas kehidupan secara moral dan material inilah yang dimaksud dengan maslahah. 25

Adanya kemaslahatan yang diperoleh oleh masyarakat pesantren setelah adanya BMT yang bisa menjadi mediasi terpenuhinya kebutuhan kehidupan mereka.26 Pernyataan ini diperkuat oleh didik beliau mengatakan bahwa

\footnotetext{
${ }^{24}$ sutono sutono, "PERILAKU KONSUMEN MUSLIM DALAM MENGKONSUMSI PRODUK HALAL FOOD PERSPEKTIF MAQA>S\} ID ALSHARI’AH AL-SYATIBI (Studi Pada Pasar Sepanjang -Taman-Sidoarjo)” (Surabaya, UIN Sunan Ampel Surabaya, 20I8).

${ }^{25}$ Sutono, "GUARANTEE OF SOCIAL NEEDS IN ISLAMIC ECONOMIC PERSPECTIVE," Jurnal Inovasi Penelitian (JIP) I, no. 8 (January 202I): I647-62.

${ }^{26}$ Nurhudah, Wawancara, Gresik 13 April 202I.
}

90| Al-Iqtishod Volume. 9/No. 2/Juli 202I 
setelah adanya BMT saya bisa menjalankan bisnis kecambah dengan modal hutang dari BMT dengan aqad qardul hasan dengan pinjam sejumlah Rp. 5.000.000 kemudian pengembalian dengan saya cicil perbulan Rp. 500.000 sampai IO bulan. Tidak ada tambahan dalam hutang saya, saya terima dari BMT Rp. 5.000.000 dan saya kembalikan juga sejumlah Rp. 5.000.000. dengan cara mengangsur sehingga membuat saya ringan dan tetap bisa mengembangkan usaha cukulan saya. 27

Sebagai seorang pengajar, saya merasa terbantukan secara kebutuhan ekonomi dengan memanfaatkan BMT untuk ajang pengajuan pembiayaan jual beli computer, jual beli rumah, jual beli tanah kavling. Kemudahan untuk mengajukan pembiayaan tanpa jaminan membuat kemudahan dalam proses jual beli yang saya lakukan dengan melalui aqad bagi hasil dengan BMT. BMT merasa banyak mendapatkan keuntungan dari proses akad Mudharabah yang saya lakukan, saya selaku mudharib dan BMT selaku shohibul maal dengan pembagian keuntungan BMT mendapat $65 \%$ dan saya mendapatkan $35 \% .28$

\section{E. Simpulan}

Baitul Maal wat Tamwil KSPPS Khoiru Ummah merupakan lembaga yang menghimpun, mengelola dan menyalurkan dana. Oleh sebab membutuhkan sumbersumber dana yang akan dikelola. Adapun sumber-sumber dana Baitul Mall wat Tamwil antara lain adalah modal, titipan dan investasi.perbankan syariah juga menawarkan nasabah dengan produk perbankan. Adapun produk-produk yang ditawarkan seperti mudharabah, musyarakah, murabahah, rahn, dsb. Produk-produk yang ditawarkan sudah tentu sangat Islami, termasuk dalam memberikan pelayanan kepada nasabahnya.

${ }^{27}$ Didik, Wawancara, Gresik IO Mei 202I.

${ }^{28}$ Syamsul Anam, Wawancara, Gresik 20 Mei 202I.

Volume. 9/No. 2/Juli 202I Al-Iqtishod |9I 
Produktivitas Baitul Maal Wat Tamwil ...

Fungsi dan operasional BMT sebagai mediasi gerakan ekonomi masyarakat pesantren yang berbasis syari'ah telah menunjukkan adanya perubahan ekonomi masyarakat pesantren menjadi lebih baik dan maslahah dalam pemenuhan kebutuhan kehidupan mereka.

\section{F. Daftar Pustaka}

Ahmad Syifaul Anam. "IMPLEMENTASI HUKUM JAMINAN LEMBAGA KEUANGAN MIKRO SYARI'AH (STUDI KASUS BMT DI KOTA SEMARANG)." Universitas Diponegoro, 2009, I-I2I.

Ilyas, Rahmat. "Etika Konsumsi dan Kesejahteraan dalam Perspektif Ekonomi Islam." at- Tawassuth I, no. I (2016): I52-72.

Mudzakkir, Muhammad Fakhruddin, and Andi Nu Graha. "Tinjauan Syariah Tentang Penerapan Akad Ijarah Al Muntahiyah Bi Al-Tamlik Di Perusahaan Leasing Syariah.” An-Nisbah: Jurnal Ekonomi Syariah I, no. 2 (April I5, 2015): 69-84. https://doi.org/I0.21274/an.2015.1.2.69-84.

Sutono. "GUARANTEE OF SOCIAL NEEDS IN ISLAMIC ECONOMIC PERSPECTIVE." Jurnal Inovasi Penelitian (IIP) I, no. 8 (January 202I): 1647-62.

—. "IMPLIKASI AKAD MUSYARAKAH MUTANAQISAH PERBANKAN SYARI'AH (Studi Peluang Dan Resiko Di Bank Mu'amalat Surabaya).” $A L$ IQTISHOD: Jurnal Pemikiran Dan Penelitian Ekonomi Islam 8, no. 2 (July 2020): I-I9.

sutono, sutono. "PERILAKU KONSUMEN MUSLIM DALAM MENGKONSUMSI PRODUK HALAL FOOD PERSPEKTIF MAQA>S\} ID ALSHARI'AH ALSYATIBI (Studi Pada Pasar Sepanjang -Taman-Sidoarjo).” UIN Sunan Ampel Surabaya, 2018.

92| Al-Iqtishod Volume. 9/No. 2/Juli 202I 
kambali, muhammad. 202I. "PRODUK OPERASIONALISASI BANK SYARI'AH : STUDI PENERAPAN PRINSIP SYARI'AH PADA BANK SYARI'AH MANDIRI (BSM) DAN BANK ISLAM MALASYA BERHARD (BIMB)". AL IQTISHOD: Jurnal Pemikiran Dan Penelitian Ekonomi Islam 9 (I), 20-35. https://jurnal.staialazharmenganti.ac.id/index.php/AlIqtishod/article/view/225.

M. Nur Rianto Al Arif, Dasar-dasar pemasaran, (Bandung: Alfabeta, 20I2).

Mardani, Fiqh Ekonomi Syariah, (Jakarta: kencana prenadamedia group,20I3).

Kautsar Riza Salman, Akuntansi perbankan syariah, (Padang: Akademia Permata, 2012), 199.

Abdur Rohman, Ekonomi Al-Ghazali, Menelusuri Konsep Ekonomi Islam dalam Ihya' Ulum Ad-din (Surabaya: Bina Ilmu, 2010).

Chapra, Umer. Islam dan Tantangan Ekonomi, Jakarta: Gema Insani Press, 2000

Volume. 9/No. 2/Juli 202I A1-Iqtishod|93 